\title{
TRAUMA REMAJA KORBAN KONFLIK BERSENJATA DAN TSUNAMI DI ACEH
}

\author{
Fonny Hutagalung, Kusmawati Hatta, dan Zahari Ishak \\ University Malaya
}

\begin{abstract}
ABSTRAK
Kajian trauma dalam kalangan remaja mangsa konflik dan tsunami di Aceh dilakukan kerana beberapa asumsi iaitu Aceh dalam sejarah yang berpanjangan telah berlaku konflik bersenjata, selain itu juga telah terjadi gempa yang maha dahsyat yang dibarengi dengan tsunami. Peristiwa tersebut telah membuat ramai masyarakat terutama remaja mengalami kesan trauma pada taraf yang sederhana, dan terdapat perbezaan yang signifikan pada setiap wilayah, sumber trauma dan jantina yang memerlukan pengkawalan secara profesional terutamanya wilayah-wilayah yang hasil ujian post hoc sangat berbeza seperti di Bireun, Aceh Selatan dan Abdya agar remaja yang mengalami trauma dapat hidup secara munasabah dan dapat merancang kehidupan yang selesa dimasa hadapan melalui layanan kaunseling trauma. Kajian ini menggunakan manual standar Trauma Symptom Inventory (TSI) yang sudah diubah pakai sesuai dengan bahasa tempatan. Manual ini dibahagi kedalam dua sakala iaitu Skala Validiti dan Skala Klinikal. Remaja yang merespon indikator tersebut dengan skor tinggi maka dapat dikatakan mereka mengalami trauma dan memerlukan pengkawalan yang serius agar tidak menjadi Post Traumatic Syndrome Disorder (PTSD). Trauma ini sangat membahaya kerana dapat menggangu kesehatan fizikal dan psikis dan bila berpanjangan akan menyebabkan sakit mental.
\end{abstract}

Kata-kata kunci: Trauma, Trauma Symptom Inventory, Post Traumatic Stress Disorder

\section{TRAUMA AMONG ADOLESCENTS VICTIM OF ARMED CONFLICT AND TSUNAMI IN ACEH}

\begin{abstract}
The research about trauma among adolescents that experience the tsunami and conflict in Aceh was conducted basing on several assumptions. A long-term conflict and a great earthquake which followed by tsunami has happened in Aceh. Those events have made many citizen especially adolescents to experience trauma at intermediate level and there was a significant differences from one place to another. Trauma sources and adolescents that requires professional support are mainly needed in places of which the post hoc test showed significant differences, such as in Bireun, South Aceh, and Abdya so that the adolescents that suffered from trauma could live on better life in the future by following trauma counseling. This research uses the standard manual of Trauma Symptom Inventory (TSI) that has been adapted in accordance to the local language. The manual was distinguished into two scale, Validity Scale and Clinical scale. Individuals who responded the indicators highly were regarded as highly traumatized and in need of serious support to avoid being developed to the Post Traumatic Syndrome Disorder (PTSD). This trauma is dangerous because it may give rise to physical and psychological health problems and more likely to cause mental illness.
\end{abstract}

Keywords: Trauma, Trauma Symptom Inventory, Post Traumatic Stress Disorder

Trauma merupakan luka yang di alami oleh seseorang, dikesan akibat suatu peristiwa yang tidak dijangka dan sangat menakutkan, seperti ancaman pembunuhan, kemalangan, bencana alam, perang, dan kejadian-kejadian yang boleh membuat mangsa berasa ketakutan, kebimbangan yang melampau, tertekan dan murung. Peristiwa tersebut boleh menimpa sesiapa sahaja di dalam dunia ini baik yang berumur sifar tahun sampai dengan warga emas, ap abila tidak dikawal

*Korespondensi mengenai penelitian ini dapat dilayangkan kepada Fonny Hutagalung melalui email: fonny@um.edu.my dengan baik dan benar dapat menyebabkan gangguan fizikal dan juga psikis. Shapiro (1999) menyatakan trauma merupakan pengalaman hidup yang mengganggu keseimbangan biokimia dari sistem pengolahan maklumat psikologi otak. Keseimbangan ini menghalang pemprosesan maklumat untuk meneruskan proses tersebut dalam mencapai suatu adaptif, sehingga persepsi, emosi, keyakinan dan makna yang diperolehi dari pengalaman tersebut "terkunci" dalam

Rekomendasi mensitasi:

Hutagalung, F., Hatta, K., \& Ishak, Z. (2013).

Trauma remaja korban konflik bersenjata dan tsunami di Aceh. Psikologia, 8(2), 1-11. 
sistem saraf. Jarnawi, (2007) menyatakan bahawa trauma merupakan gangguan psikologi yang sangat berbahaya dan mampu merosakkan keseimbangan kehidupan manusia. Cavanagh dalam Mental Health Channel (2004) menyatakan tentang pengertian trauma adalah suatu peristiwa yang luar biasa yang menimbulkan luka dan perasaan sakit, tetapi juga sering diertikan sebagai suatu luka atau perasaan sakit berat akibat sesuatu kejadian luar biasa yang menimpa seseorang langsung atau tidak langsung baik luka fizikal maupun luka psikis atau kombinasi kedua-duanya. Berat ringannya suatu peristiwa akan dirasakan berbeza oleh setiap orang, sehingga pengaruh dari peristiwa tersebut terhadap perilaku juga berbeza antara seseorang dengan orang lain.

Pasca trauma biasanya akan memperlihatkan pelbagai gejala di luar kebiasaan orang pada umumnya. Kanakkanak yang pernah mengalami trauma dan hidup dalam lingkungan yang mengancam atau berbahaya, mereka mungkin akan mengalami trauma berpanjangan yang boleh menghasilkan PTSD(Post Trauma Symptom Dysorder) dan apabila berhadapan dengan trauma baru, mereka akan bertindak balas mengikut pengalaman lepas sebagai sumber kekuatan sehingga mampu menghadapinya. Kejadian kehilangan atau kepahitan yang berulangulang dalam diri seseorang akan meningkatkan kebolehan atau kemampuan seseorang menghadapi kesedihan dan kesengsaraan mental dan fizikal. Biasanya kesan psikologi akan terdapat seperti pengasingan diri, mengelak untuk mempertahankan diri daripada terkenang kembali secara terinci tentang apa yang telah berlaku, terlalu berhati-hati dengan perkara-perkara yang seakan-akan tragedi yang menjadikannya trauma.

American Psychiatric Association (APA) (2000) dalam Diagnostic and Statistical Manual of Mental Disorder (DSM.IV-TR), menyatakan ledakan trauma merangkumi salah satu atau dua daripada berikut, iaitu: (1) seseorang yang mengalami, menyaksikan atau berhadapan dengan kejadian ngeri yang menyebabkan kematian, kecederaan serius atau mengancam fizikal diri atau orang lain, (2) tindak balas individu terhadap ketakutan, rasa tiada harapan, horror (kanak-kanak mungkin mengalmi kecelaruan tingkahlaku). Webb (2004) menyatakan bahawa: (1) trauma ditakrifkan sebagai kesakitan yang dialami oleh seseoarang yang boleh memberi kesan kepada fizikal dan psikologi seseorang sehingga membawa kesan kepada kehidupan seperti menurunnya tahap produktifiti dan aktiviti keseharian, (2) trauma berlaku kerana peristiwa pahit sama ada fizikal dan mental yang menyebabkan kerosakan serta merta kepada tubuh atau kejutan pada minda, (3) trauma berlaku kerana terdapat kebimbangan yang melampau atau kebimbangan yang traumatik oleh kesan fizikal dan psikologikal yang boleh menyebabkan gangguan emosi yang dicetuskan oleh peristiwa pahit yang akut, (4) trauma adalah peningkatan gejala tekanan (stress) yang menyebabkan gangguan emosi kepada kanak-kanak atau pelajar sekolah sehingga menyebabkan perubahan tingkahlaku, emosi dan pemikiran, (5) trauma juga dikatakan sebagai kecederaan tubuh yang disebabkan oleh tenaga fizikal dari luar seperti tembakan, kebakaran, kemalangan, tikaman senjata tajam, luka akibat bergaduh, dirogol, kecuaian teknologi dan sebagainya.

Sementara itu seorang psikiater di Jakarta Roan (2003) menyatakan trauma berarti cidera, kerusakan jaringan, luka atau shock. Sedangkan trauma psikis dalam psikologi diertikan sebagai kecemasan hebat dan mendadak akibat peristiwa dilingkungan seseorang yang melampaui batas kemampuannya untuk bertahan, mengatasi atau menghindar. Everly \& Lating, (1995) menyatakan bahawa trauma adalah peristiwa-peristiwa di luar kelaziman pengalaman manusia pada umumnya, yang terlihat sangat nyata 
dan jelas dan menyedihkan, sehingga menimbulkan reaksi ketakutan yang hebat, ketidak berdayaan, seram dan lain-lain. Vikram (2003) peristiwa traumatik adalah suatu peristiwa yang menyebabkan ketakutan dalam kehidupan seseorang dan menimbulkan stress yang negatif. Selanjutnya Yule,W (1999) dan Hughes (1991) menjelaskan bahawa peristiwa yang boleh mencetuskan terjadinya trauma adalah ancaman serius terhadap kehidupan seseorang atau ancaman terhadap fizikalnya. Spencer Eth, seorang psikiater anak yang mengambil pakar PTSD anak, (dalam Daniel Goleman, 2000) menyatakan bahawa, trauma itu adalah masuknya ingatan tentang keganasan yang menjadi focus utama, berupa pukulan, tusukan sebilah pisau, tembakan senjata. Ingatan merupakan pengalaman persepsi yang hebat terhadap penampakan. Sehingga mangsa yang kadang diam, tibatiba histeria bila mendengar bunyi, atau bau mesiu, jeritan, muncratnya darah, mahupun terdengar sirene polis. Selain itu juga, gangguan psikologi akibat kejadian traumatik, pada dasarnya timbul kerana terlalu mudahnya amigdala tergugah (stelan amigdala yang terlalu rendah). Chaplin (2001) menjelaskan bahawa amigdala merupakan suatu zat abu-abu yang terdapat dalam otak besar, fungsinya berasosiasi dengan pengawal terhadap tingkah laku agresif. Selanjutnya Daniel Goleman (2000) menyebutkan bahawa pesakit trauma mengalami perubahan litar limbic yang terpusat pada amigdala, mempunyai lokus seruleus yang di dalamnya terdapat katekolamin yang mengandungi dua jenis bahan kimia iaitu: adrenalin dan noradrenalina. Dua zat kimia ini berfungsi sebagai mobilitasasi tubuh untuk menghadapi keadaan kecemasan (bertempur atau lari). Jadi pada pesakit trauma, sistem pada amigdala sangat aktif sehingga membuat katekolamin melepaskan bahan kimia otak dengan dosis yang berlebihan untuk memberi respons situasi-situasi yang terkadang tidak kecemasan atau tidak mengancam.

\section{METODE}

\section{Partisipan}

Seramai 1185 remaja mangsa konflik bersenjata dan tsunami telah dipilih menjadi subjek kajian pendekatan kuantitatif yang tersebar di SLTA di 8 wilayah konflik dan 4 wilayah tsunami dan 120 orang untuk subjek yang dipilih berdasarkan purposive sampling dengan pendekatan kualiatatif yang dilakukan melalui interviewl bersemuka.

\section{Alat ukur}

Alat kajian yang digunakan untuk melihat kesan, tahap, perbezaan trauma dalam kalangan remaja dan pengaruh wilayah, sumber trauma dan jantina dilakukan dengan pendekatan kuantitatif adalah trauma symptom inventory (TSI) yang dipopulerkan oleh Briere, J (1995) yang terbahagi ke dalam dua skala iaitu skala pertama adalah validiti dengan indikator Atypical Response (ATR), Response Level (RL) dan Inconsistent Response (INC) dan skala kedua adalah klinikal yang dibagi ke dalam empat dimensi iaitu Dysporic Mood terdiri dari tiga indikator iaitu: Anxious Arousal (AA), Depression (D) dan Anger Iritability (AI); Post Traumatic Stress Disorder (PTSD) terdiri dari tiga indikator iaitu: Intrusive Experience (IE), Defensive Avoidance (DA) dan Dissociation (DIS); Sexual Dysfunction terdiri dari dua indikator iaitu; Sexual Conserns (SC) dan Dysfunction Sexual Behavior (DSB); dan Self Dysfunction terdiri dari dua indikator Inpaired self Reference (ISR) dan Tension Reduction Behavior (TRB). Pemarkatan inventory ini adalah semakin tinggi skor yang diperoleh maka semakin tinggi tahap trauma yang di alami subjek. Sedangkan untuk kajian kualitatif pengkaji merumuskan empat soalan yang dilakukan secara bersemuka dengan subjek kajian. 
Kajian ini dilakukan untuk menyokong dapatan kebenaran hasil pendekatan kuantitatif.

\section{Definisi istilah}

Definisi istilah dibawah ini adalah mengikut DSM IV (Diagnostic And Statistical Manual of Mental Disorders IV), yaitu:

\section{Atipikal Response(}

ATR) didefinisikan sebagai kecenderungan seseorang untuk berespon berbeda atau berlawanan seperti orang ramai. Atau dapat dikatakan tindakannya adalah berbeda dari orang biasa.

2. Response Level (RL) adalah respon yang tidak lazim yang dimunculkan oleh seseorang yang pernah mengalami pengalaman yang tidak menyenangkan.

3. Inconsistent Response (INC) adalah respon yang tidak konsisten dimunculkan oleh individu.

4. Dysporic Mood (gangguan perasaan) termasuk didalamnya anxious arousal, depression, anger irritability adalah adanya perasaan yang tidak gembira, ketidakbahagiaan, perasaan menderita, tidak tenang, perasaan murung, marah, sedih, dan rasa cemas yang dialami seseorang disebabkan pengalaman-pengalaman hidup yang tidak menyenangkan.

5. Post Traumatic Stress Disorder (PTSD) termasuk didalamnya intrusive experience, defensive avoidance dan dissociation adalah gangguan pasca traumatis seperti perasaan tidak menentu (terganggu), suka menghindar dari sosial, dan adanya perasaan terasing bahkan lebih parah lagi suka menyakiti diri sendiri ataupun orang lain. Gangguan ini terjadi akibat pengalaman atau truma yang alami seseorang yangmana pengalaman tersebut merupakan pengalaman hidup yang sangat memeritkan, menyedihkan maupun mengerikan untuk diingat.

6. Sexual Dysfunction termasuk didalamnya sexual concern dan dysfunction sexual behavior adalah ketidakfungsian seksual yang diakibatkan mengalami trauma dimasa lalu, seperti: remaja tersebut menjadi impontesi awal, gejala homoseksual, dsb.

7. Self Dysfunction termasuk didalamnya inparred self reference dan tension reduction behavior adalah ketidakfungsian diri secara optimal akibat trauma yang dialami seseorang, seperti: tahap self esteem(percaya diri) yang sangat rendah, mempunyai perasaan negatif terhadap diri, merasa diri tak berarti bahkan lebih parah lagi suka membenci diri sendiri.

\section{Analisa data}

Data yang diperolehi telah dianalisis menggunakan program SPSS versi 13, untuk melihat kesan dan tahap trauma digunakan ujian ANOVA dan untuk perbezaan kesan trauma juga dilakukan ujian ANOVA dan ujian post hoc multiple Comparisons Scheffe kerana pemboleh ubah lebih dari dua, untuk melihat perbezaan tahap trauma pada jantina menggunakan ujian t-test dan untuk mengetahui sumbangan wilayah, sumber trauma di gunakan ujian regresi.

\section{Hipotesis}

1. Terdapat kesan trauma yang signifikan pada respon skala validiti dan klinikal (TSI).

2. Tahap trauma remaja Aceh mengikut wilayah adalah tahap sederhana.

3. Tahap trauma remaja Aceh mengikut sumber trauma adalah tahap sederhana

4. Tahap trauma remaja Aceh mengikut perbedaan jenis kelamin adalah tahap sederhana 
5. Terdapat perbezaan trauma pada skala validiti mengikut antar wilayah di Aceh.

6. Terdapat perbezaan trauma pada semua indikator (skala validiti dan klinikal)

7. Terdapat sumbangan yang signifikan perbedaan wilayah Aceh ke atas semua indikator trauma (skala validiti dan klinikal).

8. Terdapat sumbangan yang signifikan perbedaan sumber trauma ke atas semua indikator trauma (skala validiti dan klinikal).

\section{HASIL}

\section{Hipotesis 1}

Jadual 1 menunjukkan hasil ujian ANOVA ke atas Ha.1 adalah di terima, kerana terdapat kesan trauma yang sangat signifikan pada respon skala validiti TSI, iaitu $p=0.001$. Nilai ini lebih kecil dari nilai kebeertian yang ditetapkan $(p<$ 0.05). Untuk lebih detail lihat Jadual 1.

\section{Hipotesis 2}

Jadual 2 menunjukkan keputusan hipotesis (Ha.2) adalah diterima kerana tahap trauma remaja berdasarkan wilayah berada purata pada peringkat sederhana, walaupun skor rendah dan tinggi juga ada. Skor tinggi $>20 \%$ hanya pada skala klinikal dimensi PTSD dan pada self Dysfunction pada indikator ISR. Untuk lebih detail lihat Jadual 2.

\section{Hipotesis 3}

Jadual 3 menunjukkan keputusan hipotesis (Ha.3) adalah diterima kerana tahap trauma remaja berdasarkan sumber trauma berada purata pada peringkat sederhana, walaupun skor rendah dan tinggi juga ada. Skor tinggi $>20 \%$ hanya pada skala klinikal dimensi PTSD dan pada self Dysfunction pada indikator ISR. Untuk lebih detail lihat Jadual 3.

\section{Hipotesis 4}

Jadual 4 dan 6 menunjukkan keputusan hipotesis (Ha.4) adalah diterima kerana tahap trauma remaja berdasarkan Jantina berada purrata pada peringkat sederhana, walaupun skor rendah dan tinggi juga ada. Skor tinggi $>20 \%$ hanya pada skala klinikal dimensi PTSD dan pada self Dysfunction pada indikator ISR. Untuk lebih detail lihat Jadual 4 dan 6.

\section{Hipotesis 5}

Jadual 5 menunjukkan keputusan Hipotesis (Ha.5) adalah diterima, kerana dapatan kajian ujian ANOVA dan Post Hoc Multiple Comparisons Scheffe menunjukkan perbezaan antara wilayah yang signifikan. Terutama Bireun, Kota Banda Aceh, Aceh Selatan dan Abdya. Untuk detail lihat Jadual 5.

\section{Hipotesis 6}

Jadual 7 menunjukkan keputusan hipotesis (Ha.6) adalah di terima, kerana hasil ujian Post Hoc Multiple Comparisons Scheffe menujukkan perbezaan sumber trauma berdasarkan pada respon semua indikator pada aras signifikan $95 \%$. Keputusan menunjukkan bahawa perbezaan min semua indikator yang sangat kentara terlihat adalah pada sumber konflik. Untuk lebih detail lihat Jadual 5.

\section{Hipotesis 7}

Jadual 6 keputusan regresi menunjukkan sumbangan wilayah ke atas respon indikator dimensi validiti ATR, RL dan INC maka hipotesis (Ha.7) ada yang di terima ada pula yang ditolak. Diterima pada indikator ATR kerana keputusan menunjukkan $\mathrm{F}=(10.716)<0.05$ dan $\mathrm{R}=$ 0.095 (9.5\%). Sedangkan RL dan INC adalah di tolak. Untuk lebih detail lihat Jadual 7.

\section{Hipotesis 8}

Jadual 8 keputusan regresi menunjukkan sumbangan sumber trauma- 
Jadual 1 Hasil ANOVA skala Validity dan klinikal dengan indikator masing-masing dimensi

\begin{tabular}{llcccc}
\hline \multirow{2}{*}{ Skala } & Indikator & \multirow{2}{*}{ N } & \multicolumn{3}{c}{ Validity Dimensi } \\
\cline { 4 - 6 } Validiti & Atypical respon (ATR) & 1185 & 15.251 & 13.705 & 0.000 \\
& Respon Level (RL) & 1185 & 3.977 & 3.392 & 0.000 \\
\multirow{3}{*}{ Klinikal Dysphoric Mood } & 1185 & 10.934 & 5.602 & 0.000 \\
& Inconsistent Respon (INC) & 1185 & 22.324 & 7.795 & 0.000 \\
& Anxiuos Arousal (AA) & 1185 & 22.872 & 7.261 & 0.000 \\
Klinikal & Depression (D) & 1185 & 23.213 & 6.753 & 0.000 \\
PTSD & Anger Irritability (AI) & 1185 & 18.882 & 4.307 & 0.000 \\
& Intrusive Experience (IE) & 1185 & 23.328 & 3.326 & 0.000 \\
Klinikal Sexual Dyunction & Defensive Avoidance (DA) & 1185 & 19.075 & 10.167 & 0.000 \\
& Dissociation (DIS) & 1185 & 17.125 & 8.377 & 0.000 \\
Klinkal Self Dysfunction & Sexual Concerns (SC) & 1185 & 12.512 & 7.744 & 0.000 \\
& Dysfunction Sexual Behavior & 1185 & 21.490 & 7.307 & 0.000 \\
& Inpairred Self Reference (ISR) & 1185 & 22.340 & 5.168 & 0.000 \\
\hline
\end{tabular}

Jadual 2 Tahap trauma berdasarkan wilayah

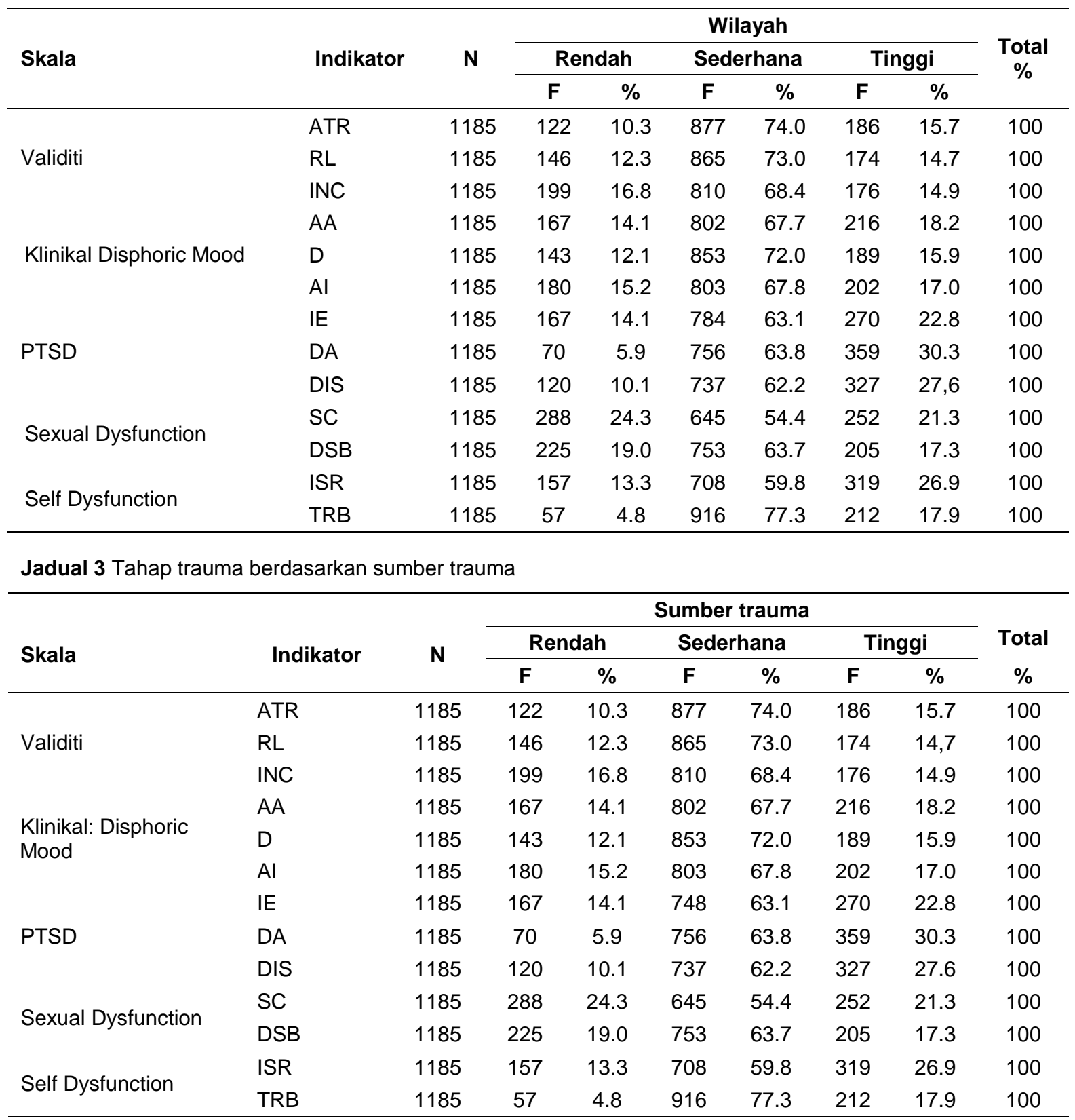


Jadual 4 Tahap trauma berdasarkan jantina

\begin{tabular}{|c|c|c|c|c|c|c|c|c|c|}
\hline \multirow{3}{*}{ Skala } & \multirow{3}{*}{ Indikator } & \multirow{3}{*}{$\mathbf{N}$} & \multicolumn{6}{|c|}{ Jenis kelamin } & \multirow{3}{*}{$\begin{array}{c}\text { Total } \\
\%\end{array}$} \\
\hline & & & \multicolumn{2}{|c|}{ Rendah } & \multicolumn{2}{|c|}{ sederhana } & \multicolumn{2}{|c|}{ Tinggi } & \\
\hline & & & $\mathbf{F}$ & $\%$ & $\mathbf{F}$ & $\%$ & $\mathbf{F}$ & $\%$ & \\
\hline \multirow{3}{*}{ Validiti } & ATR & 1185 & 122 & 10.3 & 877 & 74.0 & 186 & 15.7 & 100 \\
\hline & $\mathrm{RL}$ & 1185 & 146 & 12.3 & 865 & 73.0 & 174 & 14.7 & 100 \\
\hline & INC & 1185 & 199 & 16.8 & 810 & 68.4 & 176 & 14,9 & 100 \\
\hline \multirow{4}{*}{$\begin{array}{l}\text { Klinikal: } \\
\text { Disphoric } \\
\text { Mood }\end{array}$} & AA & 1185 & 167 & 14.1 & 802 & 67.7 & 216 & 18.2 & 100 \\
\hline & $\mathrm{D}$ & 1185 & 143 & 12.1 & 863 & 72.0 & 189 & 15.9 & 100 \\
\hline & $\mathrm{Al}$ & 1185 & 180 & 15.2 & 803 & 67.8 & 202 & 17.0 & 100 \\
\hline & IE & 1185 & 167 & 14.1 & 748 & 63.1 & 270 & 22.8 & 100 \\
\hline \multirow[t]{2}{*}{ PTSD } & DA & 1185 & 70 & 5.9 & 756 & 63.8 & 359 & 30.3 & 100 \\
\hline & DIS & 1185 & 120 & 10.1 & 737 & 62.2 & 327 & 27.6 & 100 \\
\hline \multirow{2}{*}{$\begin{array}{l}\text { Sexual } \\
\text { Dysfunction }\end{array}$} & SC & 1185 & 288 & 24.3 & 645 & 54.4 & 252 & 21.3 & 100 \\
\hline & DSB & 1185 & 225 & 19.0 & 753 & 63.7 & 205 & 17.3 & 100 \\
\hline \multirow{2}{*}{$\begin{array}{l}\text { Self } \\
\text { Dysfunction }\end{array}$} & ISR & 1185 & 157 & 13.3 & 708 & 59.8 & 319 & 26.9 & 100 \\
\hline & TRB & 1185 & 187 & 15.8 & 778 & 65.7 & 220 & 18.6 & 100 \\
\hline
\end{tabular}

Jadual 5 Hasil ujian post hoc perbezaan min pada semua indikator

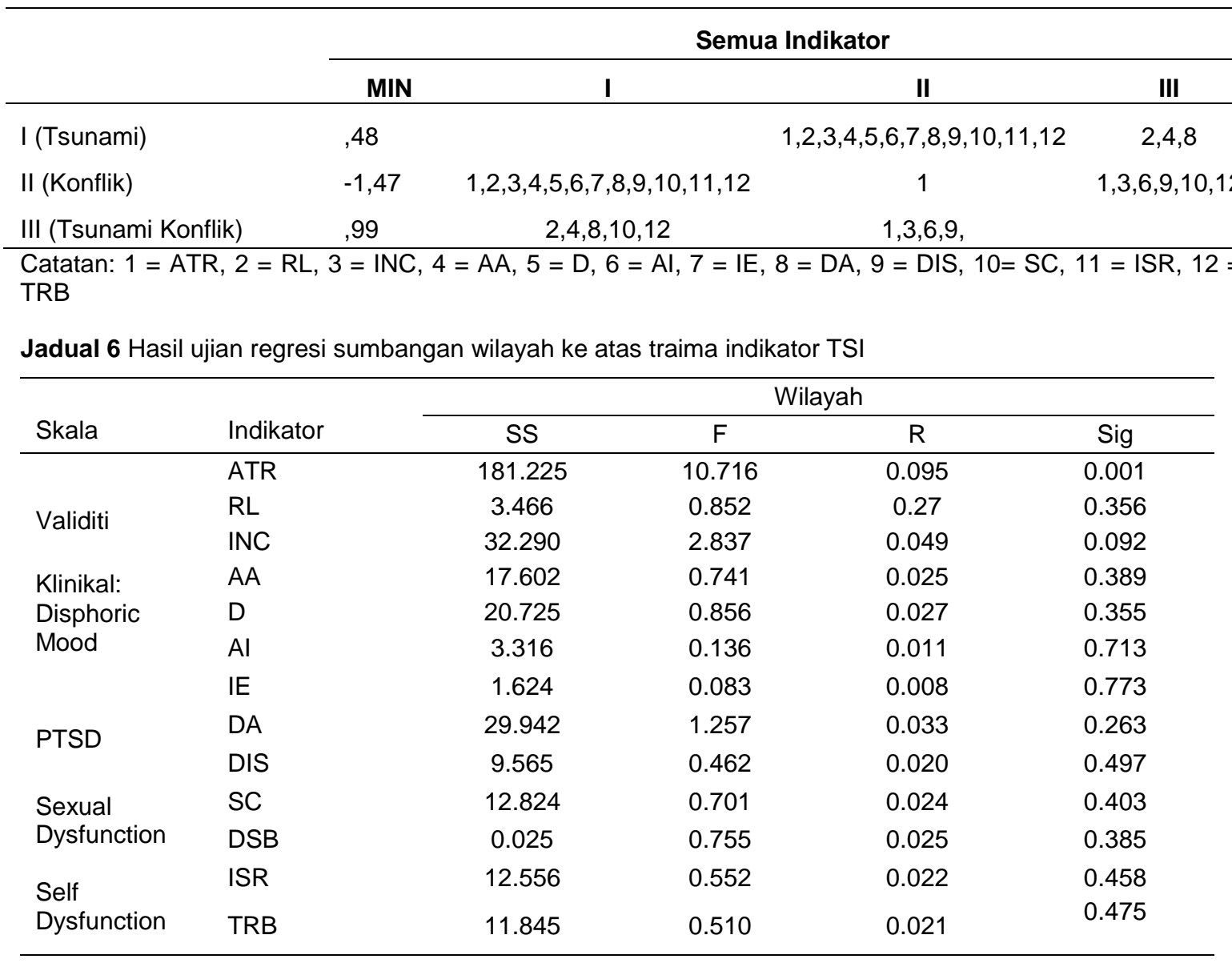


Jadual 7 Perbedaaan trauma berdasarkan jenis kelamin

\begin{tabular}{|c|c|c|c|c|c|c|c|c|}
\hline \multirow[b]{2}{*}{ Skala } & \multirow[b]{2}{*}{ Indikator } & \multirow[b]{2}{*}{ Jantina } & \multicolumn{6}{|c|}{ T- Test } \\
\hline & & & $\mathbf{N}$ & Mean & $\mathbf{F}$ & sig & $\mathbf{T}$ & sig \\
\hline \multirow{6}{*}{ Validiti } & \multirow{2}{*}{ ATR } & Lelaki & 451 & 5.0488 & \multirow[t]{2}{*}{3.493} & \multirow[t]{2}{*}{062.} & 1.909 & 057. \\
\hline & & Perempuan & 734 & 4.5791 & & & 1.862 & 063. \\
\hline & \multirow{2}{*}{$\mathrm{RL}$} & Lelaki & 451 & 2.7118 & \multirow[t]{2}{*}{1.121} & \multirow[t]{2}{*}{290.} & 2.776 & 006. \\
\hline & & Perempuan & 734 & 2.3794 & & & 2.708 & 007. \\
\hline & \multirow{2}{*}{ INC } & Lelaki & 451 & 7.0732 & \multirow[t]{2}{*}{930.} & \multirow[t]{2}{*}{335.} & 1.683 & 093. \\
\hline & & Perempuan & 734 & 6.7359 & & & 1.664 & 097. \\
\hline \multirow{6}{*}{$\begin{array}{l}\text { Klinikal: } \\
\text { Disphoric } \\
\text { Mood }\end{array}$} & \multirow{2}{*}{$A A$} & Lelaki & 451 & 9.8115 & \multirow[t]{2}{*}{301.} & \multirow[t]{2}{*}{584.} & 643-. & 520. \\
\hline & & Perempuan & 734 & 9.9987 & & & -.649 & 517 \\
\hline & \multirow{2}{*}{$\mathrm{D}$} & Lelaki & 451 & 7.2461 & \multirow[t]{2}{*}{1.595} & \multirow[t]{2}{*}{207.} & -3.337 & 001. \\
\hline & & Perempuan & 734 & 8.2239 & & & -3.427 & 001. \\
\hline & \multirow{2}{*}{ Al } & Lelaki & 451 & 7.4878 & \multirow[t]{2}{*}{313.} & \multirow[t]{2}{*}{576.} & -1.586 & 113. \\
\hline & & Perempuan & 734 & 7.9611 & & & -1.606 & 109. \\
\hline \multirow{6}{*}{ PTSD } & \multirow{2}{*}{ IE } & Lelaki & 451 & 8.2528 & \multirow[t]{2}{*}{015.} & \multirow[t]{2}{*}{904.} & -.109 & 913. \\
\hline & & Perempuan & 734 & 8.2815 & & & -.109 & 913. \\
\hline & \multirow{2}{*}{ DA } & Lelaki & 451 & 9.3215 & \multirow[t]{2}{*}{656.} & \multirow[t]{2}{*}{418.} & -2.770 & 006. \\
\hline & & Perempuan & 734 & 10.1233 & & & -2.791 & 005. \\
\hline & DIS & Lelaki & 451 & 8.1596 & 213. & 645. & .991 & 322. \\
\hline & & Perempuan & 734 & 7.8899 & & & 982. & 326. \\
\hline & SG & Lelaki & 451 & 5.2439 & 11.378 & 001. & 6.145 & 000. \\
\hline Sexual & & Perempuan & 734 & 3.6997 & & & 5.970 & .000 \\
\hline Dysfunction & DSR & Lelaki & 451 & 4.5432 & 39.811 & 000. & 7.380 & 000. \\
\hline & DU & Perempuan & 734 & 2.9731 & & & 6.982 & 000. \\
\hline & ISR & Lelaki & 451 & 8.6763 & 1.015 & 314. & -1.122 & 262. \\
\hline Self & $10 \mathrm{~K}$ & Perempuan & 734 & 8.9960 & & & -1.137 & 256. \\
\hline Dysfunction & TRP & Lelaki & 451 & 6.1064 & 1640 & 201 & 3.787 & 000. \\
\hline & IRD & Perempuan & 734 & 5.0241 & 1.040 & 201. & 3.334 & 001. \\
\hline
\end{tabular}

Jadual 8 Sumbangan sumber trauma respons TSI

\begin{tabular}{llcccc}
\hline \multirow{3}{*}{ Skala } & & \multicolumn{4}{c}{ Sumber Trauma } \\
\cline { 3 - 6 } & Indikator & SS & F & R & Sig \\
\hline \multirow{3}{*}{ Validiti } & ATR & 43.516 & 2.555 & 0.046 & 0.110 \\
& RL & 31.296 & 7.741 & 0.081 & 0.005 \\
Klinikal: & Disphoric & 2.369 & 0.208 & 0.013 & 0.649 \\
Mood & AA & 119.655 & 5.059 & 0.065 & 0.025 \\
& D & 133.440 & 5.534 & 0.068 & 0.019 \\
PTSD & AI & 82.824 & 3.394 & 0.053 & 0.066 \\
& IE & 158.953 & 8.217 & 0.083 & 0.004 \\
Sexual Dysfunction & SC & 189.058 & 7,980 & 0.082 & 0.050 \\
& DA & 20.435 & 0.983 & 0.029 & 0.322 \\
Self Dysfunction & DSB & 42.263 & 2,312 & 0.044 & 0.129 \\
& ISR & 37.546 & 2.828 & 0.049 & 0.093 \\
\hline
\end{tabular}


Jadual 9 Ujian post hoc perbezan respon antara wilayah pada indikator

\begin{tabular}{|c|c|c|c|c|c|c|c|c|c|c|c|c|c|c|}
\hline & \multirow[b]{2}{*}{ Wilayah } & \multicolumn{13}{|c|}{ Skala validiti } \\
\hline & & MIN & 1 & 2 & 3 & 4 & 5 & 6 & 7 & 8 & 9 & 10 & 11 & 12 \\
\hline 1 & $\begin{array}{l}\text { Aceh } \\
\text { Timur }\end{array}$ & -2.00 & & & 1 & 8,9 & & & & & & & 1 & $\begin{array}{c}1,4,6 \\
, 9\end{array}$ \\
\hline 2 & $\begin{array}{l}\text { Aceh } \\
\text { Utara }\end{array}$ & -2.00 & & & & & $\begin{array}{c}5,1 \\
0\end{array}$ & & 10 & & $\begin{array}{c}5,3 \\
10\end{array}$ & 6,7 & & \\
\hline 3 & $\begin{array}{l}\text { Lhokseu } \\
\text { mawe }\end{array}$ & -1.19 & & & & & & & & & $\begin{array}{c}3,10 \\
, 11\end{array}$ & 6 & 1 & \\
\hline 4 & Bireuen & -3.54 & $\begin{array}{c}1,8 \\
9\end{array}$ & & & & $\begin{array}{c}1,2 \\
6,8 \\
9\end{array}$ & $\begin{array}{c}1,8 \\
9\end{array}$ & 189 & $\begin{array}{c}1,8 \\
9\end{array}$ & $\begin{array}{c}148 \\
9\end{array}$ & $\begin{array}{c}1,2 \\
6,8 \\
9\end{array}$ & & \\
\hline 5 & Pijay & .16 & & 5,10 & & $\begin{array}{l}1,2, \\
6.8\end{array}$ & & & & & & & $1,3,4$ & $\begin{array}{c}1,5,6 \\
.8\end{array}$ \\
\hline 6 & Pidie & -.87 & & & & 1,8 & & & & & 3 & 6,7 & 1 & \\
\hline 7 & $\begin{array}{l}\text { Aceh } \\
\text { Barat }\end{array}$ & -.46 & & & & $\begin{array}{c}1,8 \\
9\end{array}$ & & & & & & & $1,4,, 6$ & 1,9 \\
\hline 8 & $\begin{array}{l}\text { Aceh } \\
\text { Besar }\end{array}$ & -1.09 & & & & $\begin{array}{c}1,8 \\
9\end{array}$ & & & & & & & 1,6 & \\
\hline 9 & $\begin{array}{l}\text { Banda } \\
\text { Aceh }\end{array}$ & -.16 & & $\begin{array}{l}3,6 \\
7,10\end{array}$ & $\begin{array}{c}3,6 \\
10 \\
11\end{array}$ & $\begin{array}{c}1,2 \\
4,6 \\
8,9 \\
11\end{array}$ & & 3,7 & & & & & $\begin{array}{c}1,3,4 \\
6,10\end{array}$ & $\begin{array}{c}1,2,3 \\
, 5,6\end{array}$ \\
\hline 10 & $\begin{array}{l}\text { Aceh } \\
\text { Jaya }\end{array}$ & -.34 & & & & $\begin{array}{c}1,8 \\
9\end{array}$ & & & & & & & 1 & \\
\hline 11 & $\begin{array}{l}\text { Aceh } \\
\text { Selatan }\end{array}$ & -4.09 & 1,4 & & 1 & & $\begin{array}{c}1,3 \\
48\end{array}$ & 1 & 1,4 & 1 & $\begin{array}{c}1,3 \\
4,8 \\
10\end{array}$ & 1 & 3 & \\
\hline 12 & Abdya & -3.18 & $\begin{array}{c}1,3 \\
9\end{array}$ & & & & 1,5 & & 1,9 & & $\begin{array}{c}2,4 \\
9\end{array}$ & 1 & & \\
\hline
\end{tabular}

ke atas respon indikator dimensi validiti ATR, RL dan INC maka hipotesis (Ha.8) ada yang di terima ada pula yang ditolak. Diterima pada indikator RLkerana keputusan menunjukkan $\mathrm{F}=(7.741)<0.05$ dan $\mathrm{R}=0.081(8.1 \%)$. Sedangkan dimensi dysporic mood diterima indikator AA $\mathrm{F}=$ (5.059) $<0.05, \mathrm{R}=0.065(6.5 \%)$ dan $\mathrm{D} \mathrm{F}=$ (5.534), $\mathrm{R}=0.068$ (6.8\%), Dimensi Sexual Dysfunction di terima IE $\mathrm{F}=8.217, \mathrm{R}=$ $0.083(8.3 \%)$, pada self dysfunction ISR F $=7.529, \mathrm{R}=0.080(8.0 \%)$. Selain itu di tolak. Untuk lebih detail lihat Jadual 9 di bawah.

\section{DISKUSI}

Berdasarkan keputusan kajian bahawa terdapat kesan trauma dalam kalangan remaja mangsa konflik dan tsuanmi di Aceh merupakan sesuatu yang wajar kerana Aceh dalam sajarah telah terjadi konflik berpanjangan dan juga bencana alam gempa dan tsunami, akibatnya banyak masyarakat yang trauma.
Alkhaidar (1999) menyatakan pasca MoU Helsingki antara Pemerintah Indonesia dengan pihak Gerakan Aceh Merdeka (GAM) pada tarikh 15 Ogos tahun 2005, secara jurisdiksi formal dilaksanakan dengan disahkan ketetapan Republik Indonesia No. 11 tahun 2006 tentang Pemerintahan Aceh. Sejak itu keadaan sosial masyarakat sama seperti keadaan selepas perang pada tahun 1873-1913 yang mendapat banyak "luka" pada fizikal yang berkesan dalam jiwa. Anthony Reid (2007) menggambarkan situasi tersebut sebagai "kehancuran, tekanan jiwa dansakit mental". Kondisi tersebut dapat juga dikatakan pencetus terjadinya trauma pada masyarakat terutamanya adalah remaja.

Temuan kedua dari kajian ini adalah tahap trauma yang dialami remaja mangsa konflik dan tsunami di Aceh berada pada peringkat sederhana, kerana walaupun skor rendah juga ada pada setiap wilayah, sedangkan skor tinggi juga ada pada setiap wilayah pada semua indikator dan skornya 
masih dibawah $20 \%$ hanya terdapat pada dimensi PTSD purrata pada indikator Intrusive Experience, Defensive Avoidance dan Dissociation dan pada dimensi Self Dysfunction iaitu pada indikator Inpairred Self Reference di atas 20\%. Dengan demikian dapat dinyatakan bahawa peringkat trauma yang sederhana yang dialami remaja sekarang telah mengarah kepada trauma klinis iaitu Post Traumatic Stress Disorder. Atau stres pasca peristiwa traumatik. Brewin CR et,al ( 2000) menyatakan faktor-faktor yang berisiko untuk mengalami PTSD adalah hidup dalam peristiwa trauma dan bahaya, mempunyai sejarah sakit mental, mendapat cedera, melihat orang cedera atau terbunuh, perasaan seram, tidak berdaya, atau ketakutan yang melampau, tidak mendapat sokongan sosial selepas peristiwa tersebut, berurusan dengan tekanan tambahan selepas peristiwa itu, seperti kesakitan kehilangan orang yang dikasihi, dan kecederaan, atau kehilangan kerja atau rumah. Gurvits TV, et al (2000) menyatakan faktor alam sekitar, seperti trauma kanak-kanak, kecederaan kepala, atau sejarah penyakit mental, boleh meningkatkan lagi risiko pada seseorang yang mempengaruhi pertumbuhan otak awal. Sementara itu, Charney DS (2004) menyatakan faktor yang dapat mengurangkan resiko PTSD adalah: Mencari sokongan daripada orang lain, seperti rakan-rakan dan keluarga, mencari kumpulan yang menyokong selepas peristiwa traumatik, perasaan yang baik mengenai tindakan sendiri dalam menghadapi bahaya, mempunyai strategi menghadapi keadaan yang buruk, atau mendapatkan pebelajaran daripada nya, kerana sebagian mampu untuk bertindak dan bertindak balas dengan berkesan walaupun perasaan takut.

Temuan ketiga kajian ini adalah terdapat perbezaan yang signifikan tahap trauma yang dialami remaja korban konflik dan tsunami di Aceh dilihat dari wilayah, sumber trauma dan jantina. Dan yang paling kentara perbezaannya berdasarkan ujian post hoc adalah wilayah Bireun, Aceh Selatan, Kota Banda Aceh dan Abdya. Perbezaan ini menurut pengkaji adalah perkara biasa, kerana manusia hidup dan bertindak balas sangat dipengaruhi, oleh budaya setempat, pemahaman agama, pendidikan dan juga peringkat trauma yang dialami. Hasil Kajian IOM (2006,2007) keperluan psikososial mendapati bahwa Bireun Aceh Selatan termasuk kedalam trauma tinggi, yang memerlukan sokongan dari berbagai pihak. Bila dilihat dari sumber trauma perbezaan yang sangat signifikan adalah pada sumber konflik, hal ini menunjukkan bahawa kecederaan, kesakitan, kesedihan yang dibuat oleh manusia seperti konflik bersenjata lebih berkesan kedalam jiwa berbanding dengan kesedihan, kecedraan dan kesakitan yang di datangkan oleh Allah SWT seperti bencana alam gempa dan tsunami. Kenyataan ini dibuktikan dengan hasil kajian Kusmawati (2009) yang bahawa trauma kerana konflik bersenta lebih sakit berbanding trauma pada masa tsunami

Temuan keempat kajian ini adalah sumbangan wilayah ternyata tidak begitu signifikan ke atas tahap trauma yang diderita mangsa konflik dan tsunami, hanya memberi sumbangan $9,5 \%$ pada intikator ATR, sementara sumbangan sumber trauma hanya pada indikator RL, AA, D, IE, dan ISR purrata $8 \%$.

Secara keseluruhan hasil kajian menunjukkan terdapat kesan trauma pada peringkat sederhana, dimana pada setiap wilayah, sumber trauma dan jantina terdapat perbezaan yang siginifikan terutamanya wilayah Bireun, Aceh Selatan, Kota Banda Aceh dan Abdya. Selain itu juga wilayah hanya memberi sumbangan ke atas skala validity pada memberi sumbangan keatas skala validiti adalah pada indikator Response indikator Atypical Response (ATR) sebesar 9.5\%, sementara sumber trauma Level (RL) sebesar $8.1 \%$, dan pada skala klinikal pada dimensi Dysphoric Mood pada indikator Anxious Arousal (AA) sebesar 6.5\% dan 
Depresion (D) sebesar 6.8\%, Pada dimensi PTSD pada indikator Intrusive Experince (IE) sebesar $8.3 \%$ dan pada dimensi Self dysfunction pada indikator Inpairred Self Reference (ISR) sebesar 8.0\%. Dapatan ini cukup kuat untuk merekomendasikan pada pemerintah Aceh untuk membuka layanan kaunseling trauma dalam rangka pemulihan remaja yang trauma.

\section{REFERENSI}

Al-Chaidar, (1999) Acheh Bersimbah Darah, Jakarta: Pustaka Al-Kautsar.

American Psychiatric Association (2000) Diagnostic and Statistical Manual of Mental Disorder (4th ed., text rev) Washington ,DC. Author.

American Psychiatric Association (2005) Diagnostic and statistical Manual of Mental Disorder (4thn ed,.Text rev) Washington, DC: Author

Brewin CR, Andrews B, Valentine JD. Meta-analysis of risk factors for posttraumatic stress disorder in traumaexposed adults. J Consult Clin Psychol, 68(5):748-66.

Briere, J .(1995). Trauma Symptom Inventory (TSI): Professional Manual. By Psychological Assessment Resources, Inc, (PAR) U.S.A

Chaplin, J. (2001). Kamus Lengkap Psikologi (terj.Dr Kartini Kartono). Jakarta: PT. Raja Grafindo Persada

Charney, D. S., \& Keane, T. M. (1995). The development of a clinicianadministered PTSD scale. Journal of Traumatic Stress, 8, 75-91.

Everly, G. S., Jr., \& Lating, J. M. (1995). Psychotraumatology: Key papers and core concepts in Post-Traumatic Stress.New York: Plenum.

Goleman (2000) Emotional Intelligence. Jakarta, Gramedia Pustaka Utama.

Gurvits TV, Gilbertson MW, Lasko NB, et al. Neurologic soft signs in chronic posttraumatic stress disorder. Arch Gen Psychiatry, 57(2):181-186.

Hughes. (1991). An Outline of Modern Psychiatry. Chichester: John Wiley \& Sons

Jarnawi .(2007). Konseling Trauma Untuk Anak Korban Kekerasan, IAIN ArRaniry Bekerjasama dengan CV AK Group.

Kusmawati Hatta. (2009). Perbedaan Bentuk-Bentuk Trauma Pada Remaja Korban Konflik dengan Tsunami (Kajian Pada Remaja SMU Aceh Besar. Banda Aceh: Pusat Penelitian IAIN Ar-Raniry.

Mental Health Channel, (2004), Posttraumatic Stress Dissorder (PTSD),

http://www.ncptsd.va.gov/facts/disaster s/fs_rescue_workers. html, diakses 04 Mei 2005a

Patel, Vikram (2003). Where There Is No Psychiatrist. Bell \& Bain Limited.

Reid, A. (2007). Asal Mula Konflik Aceh Dari perebutan Pantai Timur Sumatera Hingga Akhir Kerajaan Aceh Abad ke 19, (Terj. Masri Maris), Yayasan Obor, Idonesia,

Roan ,W. (2003) Melupakan Kenangan Meng -Hapus Trauma dalam Intisari, http://www.jagajaga.com/anIjakTerkini. php? ida $=$ 65234, diakses 4 Mei 2005.

Shapiro, F. (1999) Eye Movement Desensitisation and Reprocessing: Basis principle, Protocol and Procedres, New York: Guilford Press.

Vikram, P. (2003). Where There Is No Psychiatrist. Bell \& Bain Limited.UK

Webb, B. N. (2004). Mass trauma and violence. Helping and Children cope. New York: Guilford Press.

Yule,W. (1999). Post-traumatic Stress Disorder: Concept and Therapy. Baffins Lane, Chichester, England: Jhon \& Sons. 